\title{
Epiphonies of Motivation and Emotion Throughout the Life of a Cellist
}

\author{
Guadalupe López-Î́niguez \\ Sibelius Academy, University of the Arts Helsinki, Finland
}

This layered autoethnography comprises momentary scenes connected to musical pieces for cello that are engraved in my memory and on the calluses of my fingertips by significant physical, emotional, and motivational experiences that have accompanied me since my youth. My artful methodology invokes truthful memory through sound to compose a "methodology of the heart" (Pelias 2004). I thus blend music "epiphonies" and stories with past and present moments to create a thickness of duration, an épaisseur. I purposely used intersubjectivity as an evocative sensitivity when analyzing autobiographical memories to interpret cultural assumptions in the field of music education and classical music performance. These assumptions include the importance of being 'talented', the exposure to external stressors and competitiveness, and the imbalance of power relations between teachers and students. My aim is to expand understandings offorms of arts research, and to highlight certain pedagogical and social practices in the education of classical musicians that can compromise their well-being and identity construction.

Keywords: autoethnography; bullying; competitiveness; embodied cognition; emotion; flow; identity; motivation; music education; talent; well-being

\section{Prelude}

This article is composed of 6 vignettes of "aesthetic data" from important musical moments in my life that have recently served as catalysts for personal reflection (Etherington 2007). I am a product of a music culture-Western classical musicand I acknowledge that many others before and after me have likely experienced similar pitfalls, and can therefore resonate with my stories (see resonance as a rendering for a/r/t/ography; Gouzouasis 2006). I call my stories 'epiphonies'-a term that refers to a "realization that is evoked through sound"-(Gouzouasis 2013, 74), inspired by the practice of sharing epiphanies that is often found in autoethnographic writings (Ellis, Adams, and Bochner 2011; Gouzouasis and Ryu

(C) Guadalupe López-Íñiguez. The content of this article is the sole responsibility of the author. The ACT Journal and the Mayday Group are not liable for any legal actions that may arise involving the article's content, including, but not limited to, copyright infringement. 
2015). These particular vignettes are framed within autoethnographic approaches, such as the evocative (e.g. Bochner and Ellis 2016) and the interpretive, through epiphanies (Denzin 2013) of sound (Gouzouasis 2013). As this manuscript responds to the notion of layered autoethnography, I conclude with an 'exegesis' after the stories have been told, wherein I contextualize and analyze the stories through motivation and emotion theories-thus including the approach of analytic autoethnography as well (e.g. Anderson 2006).

I hope you will go out and let stories, that is life, happen to you, and that you will work with these stories from your life

-not someone elses's lifewater them with your blood and tears and your laughter till they bloom, till you yourself burst into bloom. That is the work. The only work.

(Estés 1992, 511).

\section{Epiphony 1}

I have begged my mother for a couple of years to sign me up for music studies at the conservatoire. She says we have no money for this activity. In addition, I'm the only one in the general school who, after taking the musicality tests, wasn't recommended to study music, so why should she have me study if I am not "talented"? My mother does not understand that children bully me at school. She does not understand that I am really jealous every time other children take their saxophones to the classroom and go for fun music rehearsals and lessons. They seem to enjoy it. I want to enjoy it too, and I would love to be in another place than this terrible school where nobody likes me. It is too hard to get high grades on the exams and to be loved by teachers. I am also pretty cute, but I am rather shy and often scared too. If I were unattractive, unimaginative, and ignorant, they might accept me ... or perhaps not.

My mother and I walk down the street of the conservatoire, toward our local grocery store for weekly shopping. I pass the first window of the conservatoire, then the second one, and I abruptly stop in front of the main entrance.

"Okay, Mom. If you don't sign me up now, I'll do it myself."

I fling open the door and step into the building with determination. 
“Okay, okay, let's go and ask. I don't understand why you want to study music. And be prepared for your father to say no-musical instruments are expensive, and lessons might be really costly. Besides, you aren't very musical."

It seems that she may actually be open to the idea, and she follows me into the building with curiosity.

We approach the man at the information desk.

"Hello, my daughter would like to study music, but we have no musical background at home. No idea about any of this," my mother proclaimed. "I suppose this is expensive and she will need a musical instrument. And I am also concerned whether music will interfere with her other academic studies."

"Okay, you don't have to worry about any of that," the gentleman said with a chuckle. "First of all, though this music conservatoire is private, the annual fee is really small, and your daughter can easily get provincial scholarships to cover the costs. In addition, this conservatoire, as is tradition in the Valencian province, is annexed to a symphonic band, a cultural association that uses any money from sponsors and members to provide the children with decent musical instruments.

"Also, you should know that children who study here become responsible and organized in their general school tasks, and she will make many friends and have a great deal of fun.

"She will need to have about one year of solfège training before choosing her musical instrument, but after that, she will be ready to become a musician. As of now, it takes about ten years of training before she will be able to access higher music education, then she can get the professional degree after four additional years. To make children happy, we assign musical instruments right before Christmas, taking into consideration their wishes and skills. It's like an early gift."

"Well, okay, sir. Let me discuss this with my husband and I will get back to you. It's unlikely she will study this for a long time. One has to do something useful in life. But let's try it for a while."

My mother scrutinizes me with a hopeful face to find any sign that I might want to reconsider the whole thing.

Fast forward to December 1995. It took just three months, not an entire year, to choose my instrument. I learned everything faster than expected, a trend that would continue in later stages of my musical path, and quite unexpected for somebody who had failed a musicality test. 
We are in the rehearsal space on the top floor of the conservatoire. As they do every December, teachers are playing different instruments for the children who have completed their solfège studies and are ready to choose their instruments.

If you like an instrument, then you have to raise your hand. The teachers will say how many are available and for which children. I only recognize the saxophone, piano, and violin. I know very little about music at this point ... and besides, I do not know what instrument I want to learn to play. There's an instrument that seems to need plenty of effort and it squawks like an angry duck. Another one is similar to the recorder we use in school and I hate it-it is like the devil's instrument to my sensitive ears. Instruments made of shiny brass seem to be favored by the boys, and that might encourage bullying here as well.

But wait, what is this the teacher in the black suit is playing? It is beautiful. I recognize the pitch of every string. It truly has a lovely tone. It sings to me. The shape is harmonious, like a human body. It's an enormous violin. For sure, it is used in the orchestra, so I could play classical music with it.

I immediately raise my hand with full energy so that I am noticed and they will assign it to me.

"Please, God, please. I have never asked anything from you, but this time..."

My prayers answered, I lug the instrument home.

"Damn, I didn't think it would have such an ugly case, I hope no one from the school sees me. It's also really heavy. Well, the sound of the instrument was pretty when the teacher played it. Come on, breathe. It's not that bad."

A week passes by and I have my first individual lesson, with a teacher all to myself for an hour. Unfortunately, there will be group lessons as well. Hopefully, the other students will accept me. This time, I will be myself. It doesn't even matter if others act like I don't exist. I will enjoy every minute.

I arrive home. My father is watching football in the living room. I enter with a wide smile of excitement.

"Hello, Dad. I picked the cello," I exclaim with excitement.

"It seems very big. Show me, how does it work?"

As I remove the cello from its case, he doesn't turn off the television. I feel a little sadness in my heart.

I first put the bow on an open string, and of course it bounces and shakes. But in the midst of sound production, I discover the rhythm of part of a song my father sometimes sings, the beginning of "Quinto Levanta," a traditional Spanish military 
song for the reveille, the military wake-up call. My father thinks I can't play such a thing, and that he will lose his money by investing in my new hobby.

But I ignore his reaction and wonder how to continue next. He suggests that maybe one of the hands should press the strings down against the fingerboard, exactly as the teacher did when playing the cello for the children. So I do that, but the pitch is not right. Maybe I should move my hand. I try several different positions, and then I find it. There it is. I can play a song. It is amazing.

\section{-AUDIO LINK-}

Caption for Audio Clip 1: Adaptation of "Quinto Levanta" [Spanish popular Reveille song], played by the author on a modern cello in $440 \mathrm{~Hz}$.

Meanwhile, the football match continues in the background. I don't notice the spike underneath the cello so I delicately balance it, baroque-like, in my lap.

As I practice, my mother opens the door of the house and shouts, "Can you please lower the volume of the TV? It is going to disturb the neighbors."

Great, she didn't notice I'm playing an instrument and it's not the TV. That says a lot about our musical knowledge at home.

She comes in and sees the situation.

"I don't understand why you chose such a big, loud instrument. Please, go to practice in another room."

As I move to the dining room, I realize that I have a toy with which I will have lots of fun. My parents don't care much about it. My brother will care less than they do. He still can't understand, after 12 years, why he's got a younger sister. I keep practicing little melodies. The dining room would become my sanctuary and meditation space in these first years of musical life.

\section{Epiphony 2}

It is springtime, and I have now been playing cello for one and a half years. My teacher encourages me to be myself; she is always insisting that I should figure out what I want to express with my music, and that this is different for everybody. She always asks what music I like the most. She asks lots of questions all the time, and I always feel really curious about learning new things with her because she makes the lessons really fun. At the end of the lessons she usually helps me to remember 
the new things we have learnt and we prepare a plan to practice at home. The pieces are so lovely. The sounds are so beautiful.

However, my main influence during these early years has been the orchestra conductor. He is married to my cello teacher. To get into the band, a student needs four years of instrumental training, but as I already play better than any other children in the town, I am ready. The band conductor is absolutely inspirational.

The conductor has introduced me to a new world of amazing ideas. He thinks it is crucial for a good musician to know about all kinds of things. Some are certainly weird. Zen and the art of archery, body and nutrition balance, and meditation; the fascinating personalities of Bernstein, Celibidache, and Kleiber; how to transcribe Stravinsky and Bach; why music is the highest of all arts; why it is worth sacrificing one's life to make others happy through performing music; and so much more. He is the most energetic, passionate person I have ever met. But my mother thinks this is a sect.

I can see that he favors me. For some reason his wife, my cello teacher, is not happy about it. This will become a common tendency later on as well, but I can't help it. The wife begins to unconciously bully me, and supports the other students doing so as well. Such is the end of my happy dream of not being bullied.

Luckily, the conductor makes a dream of mine come true: he makes me principal of the cello section, and even dedicates extra time to practice with me before every general rehearsal. I really develop my musicality with him because, as he says, I am a 'sponge.'

I am rewarded with a solo from the "Suite Hebraica" for symphonic band by Miguel González. There are solos for clarinet, oboe, and cello in this piece. A girl who has rich parents, and also learns her parts quickly, plays the oboe solo. I can tell from the aloof ways she looks at me that she seems to hate me. And so does her mother. For some reason my mother insists on comparing me to this girl because she is a few years younger than I, and being "too old" seems to be a problem in music studies.

Thus, I start disliking anything related to the oboist. Of course, her selfconfident, egocentric attitude is neither something I enjoy, nor is the rivalry our mothers are pressing upon us. In a small town, if you have one treasure, that is fine. But if you have two, there's so much competition there may as well be a battle in a colosseum. And if the mothers of the treasures possess limited understanding about raising a confident child in a safe manner, there is no hope. 
The concert date arrives. I've had no problems in the rehearsals. In fact, I love performing music. This is such a nice piece. It relates to the exodus, and is so melancholic and inspiring. It fits the cello well. Yet I feel odd at the same time. I start to feel nervous because the other day my cello teacher told me that people expect me to succeed and not to fail, and that everybody gets nervous during concerts. I am not an exception for her. This makes me anxious. I tell this to the conductor and a couple of adult friends who play the saxophone.

The conductor seems to understand his wife's jealousy. He tells me that before the solo starts, he will look at me-if I smile, that means I will play, and if I close my eyes, that means I won't. And it will all be fine, no stress. He will merely skip the solo.

My saxophone friends come one minute before the concert with a present-a toy bear playing the saxophone, filled with chocolates. How very nice and considerate of them. They tell me I must enjoy the concert, and that I play like an angel.

The moment comes, and I feel supported by people who really love me and believe in me. The conductor looks at me, and I am taken away by an incredible, divine force. I want to close my eyes, yet I can't help but smile. Damn, I can't take that smile back. I start playing, but it is not my fingers that do the playing. I can't control the situation.

\section{-AUDIO LINK-}

Caption for Audio Clip 2: Cello solo from the $3^{\text {rd }}$ movement of the "Suite Hebraica" for symphonic band by Miguel González, played by the author on a modern cello in $440 \mathrm{~Hz}$.

On the last note of my solo the oldest musician of the band shouts, "Bravo!" I don't know what happened, whether I played well or if I even played at all. The music continues with the whole band responding to my solo, and I join the tutti. It is very touching. They were inspired. I can sense it. The conductor smiles more than ever.

Later, I whisper to my desk colleague asking what happened.

She whispers back, "You rocked it."

She will be one of the few friends I will keep from my hometown. Though at the beginning she was not very fond of me, I learned that she has a great heart. She would later support me when she understood how others treated me. 
My parents are happy. They want more. Everyone wants more. I am finally considered as "talented" by their standards. The jealous ones are not very happy. The oboe tries her best in her solo that follows mine, but it is overly dramatic, as it will always be. Later in life, I will learn the difference between a musician and an artist.

It's magical when you get into the "flow" of a performance. For me, it has almost happened continuously since that first experience. I don't remember what happens in most of my performances, and I never experience stage fright. But after the concerts, I am absolutely out of my mind, confused and not knowing how it went. But something tells me to trust my self, and it makes my hormones so happy, so there is no way I can fail. However, when I do fail, I become very aware of every second of my performance.

A typical day is full of anxiety and boredom. Flow experiences provide the flashes of intense living against this dull background.

(Csikzentmihalyi 1990, 30-32).

\section{Epiphony 3}

It is now the autumn of 1997. I have been very active with my symphonic band, playing in summer festivals. Through my village conductor, I was introduced to the conductor of the Royal Band of the Court in Madrid. He liked my playing, and has recommended me to study with the principal cellist of the Madrid Symphonic Orchestra.

I explained to him that I come from a family with few resources, so he wants to meet my parents. The teacher agrees to take a fee from them less than his usual amount. My father is to drive me to Madrid every two weeks, about 250 kilometers each way, which is quite a lot for a single day trip. That way I can spend two to three hours with him. He studied in Paris with Tortelier, was the first person to get a cello professorship in Spain, and he seems to be a sensitive player like I am becoming.

My parents decide to take me to Madrid. This means I won't have fun excursions with my schoolmates anymore, like skiing in the mountains or visiting museums. I won't have much new clothing or any Christmas presents. Not that I have much of those anyway. That is okay, but my schoolmates continue to bully 
me. Even though the teacher is charging me less, it is still a large amount. However, whatever the conductor of the Royal Band said to my parents seems to have made a great impact in how they support me now.

They even bought me an old cello, which meant they could not use their savings for a small apartment at the beach one day, nor could they finish paying the loan on our house early, as they had planned.

For our first meeting, we drive to the teacher's studio in Madrid Center. During the next four years, I will also visit him in his fabulous house in the countryside. I have never been in an artist's house, but it is just as I would have pictured it: paintings, thousands of books and scores, sculptures, and musical instruments. He is charming with great manners, originally from the Canary Islands, very French in a sense. I have been playing cello for two years, and I bring, among other pieces, Bach's 2nd Suite, as I have discovered this incredible music during the summer.

\section{-AUDIO LINK-}

Caption for Audio Clip 3: Prélude from the $2^{\text {nd }}$ Suite in D minor BWV 1008 for solo cello by Johann Sebastian Bach, played by the author on a baroque cello in $415 \mathrm{~Hz}$ (live concert tape).

He listened carefully to my performance of the "Prélude," then remarked. "What do you think about this music?"

"It is melancholic, yet somehow very romantic. I like it a lot."

I am too shy to say anything more.

"Yes, I can see that. We are going to work on strengthening your technique. Your other teacher has done a great job, and you seem very flexible and absorb knowledge quickly. But we need to build an artist, not just a cellist. Do you know the difference?"

"An artist will be remembered, but a cellist will be forgotten?"

I say this because the conductor told me exactly the same thing, and I feel it sounds like a proper answer.

"That's right. There are many people who can play the cello. You could almost go to a kiosk and get monthly subscriptions to a magazine where they explain to you where the fingers go, how to hold the bow, where the sounds are located in the fingerboard, exercises for vibrato-like they do in guitar magazines. With patience and enough practice, anybody can become a cellist. 
"But to be a true artist is different. First of all, not everybody can be an artist, for an artist needs to suffer, to fail, to lose someone or something, to be ignored, to dedicate their life to others, to sacrifice their desires and put every ounce of effort into their art. But most importantly, an artist is a humanist and a scientist at the same time. So if you want to be an artist, the first thing to do is study something else besides music, and to read as much as possible. Still, that won't make you an artist. An artist is someone who, even when playing wrong notes or experiencing failure in a concert, is capable of touching your heart. Jacqueline du Pré was an artist, and it seems you have that kind of ability. And beautiful hands like hers."

The dozens of lessons I got from this teacher would be crucial to developing my personality as an artist, to growing my interest in other topics, and to enjoying myself even more when playing on stage. He also helped me to develop my own technique according to my type of body, hands, and fingers, and was always supportive, making me feeling special and treasured, valuing my personality. He taught me so many good technical tricks and was such a wonderful musician to learn from.

What radical constructivism may suggest to educators is this: the art of teaching has little to do with the traffic of knowledge; its fundamental purpose must be to foster the art of learning [and development]. (von Glasersfeld 1995, 192)

\section{Epiphony 4}

It is now 2001. I have been playing cello for over five years. I finished all the studies that prepare musicians to apply for the bachelor's or Superior Diploma studies within half of the usual time (10 years). My teachers have been preparing me to pass the entrance examination. I played Haydn's C Major Concerto, Saint Saens' Concerto, some capriccios by Piatti, and some technical studies by Popper.

"Now forget everything I have taught you," my teacher says, "and just say to yourself before you begin, 'I am the Queen of Sheba,' and it will all be great."

So I did what he sugegsted. And it went very well. I have always enjoyed theater, so it was fun to be the Queen of Sheba. Some people still remember this performance. There were about 40 cello applicants from the whole country, many 
of them sons or daughters of the most important musicians, and some accompanied by amazing pianists. I was the youngest, I used the pianist who was offered for free, and I earned first place with a very demanding panel of judges. Today, people still remember this performance.

Sadly, my teacher retired right after this, although I was supposed to study with him for four more years. I did not know this was coming. He didn't tell me about it, because he thought I would not focus on the exam properly. I felt cheated, but I had to continue my studies there.

I had been accepted and my parents and I knew little about other options. With the first new teacher for the first year, I learned nothing. I prepared Elgar, Lalo, Bach sonatas, and many other pieces. I was on my own. Elgar was comforting, both for my sadness about feeling lonely in the music world, and during my teenage years for not finding the love of my life.

The three remaining years before the completion of my Superior Diploma were a total nightmare. To escape from my village and life, and to feel supported, I lived with a boyfriend I didn't love. Being in a type of "marriage" at the age of 17 is not such a great idea. Elgar accompanied me for many years to come, and my salty teardrops destroyed the varnish of my cello, a daily reminder of my fate.

I then got a teacher who was terrible and punished me constantly. He also used to leer at me like I was indeed a woman, so I wished that I were unattractive, unimaginative, and ignorant. ${ }^{1}$ I used to make the sign of the cross before going to his lesson on Wednesdays. This was the same day my parents called me every week. Naturally, they wanted to see how their 'investment' was doing.

The problem with this teacher was simple. During the first lesson, he wanted me to apply for studies at some sort of reputable, foreign institution for a masters' degree, and to attend competitions. During the second lesson, he asked who my previous teacher had been. When I told him, he started bullying me, and he supported his other students in doing the same. They were extremely happy to do so, as I had received the first place prize to study there, and nobody wanted to be around someone who wasn't like them.

Now it was time to put me down, and they really did. This teacher forced me to play purely technical pieces he knew I didn't like and were completely unrealistic for my stage of development, and avoided giving me chances for concerts and visibility. From a diary I kept during those times, I found the following passage.

López-Íñiguez, Guadalupe. 2019. Epiphonies of motivation and emotion throughout the life of a cellist. Action, Criticism, and Theory for Music Education 18 (2): 157-89.

https://doi.org/10.22176/act18.2.157 
It is amazing that, although I can play demanding stuff, and there are so many wonderful pieces I still have to include in my repertoire, he punishes me with Britten Suites and Popper's Cello Concerto, and scales, thirds, sixths, octaves, and arpeggio exams. Maybe some people like that, but I want to develop as a musician through something else.

Sadly, my parents think I am a failure now and believe that this teacher has the right to treat me like this, as I seem not to practice anymore.

Don't they understand that I can't practice if I don't like the music?

Don't they understand that I'm depressed, and I don't enjoy this anymore? That I am in a context where I can't find my place, and I am not capable of hurting others and follow the mafia of the music classroom, where no one will be your friend, you remain in a certain group and shun others, and if you disagree, they will banish you.

Even when other students and I wrote a complaint letter to the director of the institution explaining how badly this teacher treats anybody he doesn't like, especially those most vulnerable, this director forwarded the letter to him instead of helping us because he supports this nasty guy, and not the students, who obviously suffer. They are the same and they support each other, because this teacher comes from an important musical family, and no way the director will let this story out.

Now it is even worse, because after he learned about the official complaint, he has told me that if I do it again, he will cut off my ponytail. It is clear that this means war!

The last year of my studies in Madrid, I failed my graduation recital. I collapsed and couldn't play a note. I had to repeat the damn exam after the summer. I passed with the lowest marks, even though I managed to play well (God knows how).

Feeling so sad led to low energy, social withdrawal, and especially a sense of limited horizon of my future. (in the line of e.g. Harter and Jackson 1993;

Damasio 1999; Mee et al. 2006; Hervas and Vázquez 2011) 


\section{Silence: An interlude}

Between 2005 when I graduated until 2012, I carried the cello with me wherever I went, but I almost never removed it from its case. This meant seven years and some extra flight tickets paid for nothing. In the meanwhile, I was introduced to a book called Masters and Learners (Pozo 2008), written by a person who later would become my PhD supervisor. That book made an incredible impact on me, and later led me to earn postgraduate diplomas in education and musicology, and to start my Ph.D. in psychology, as I tried to understand why I had suffered this loss of motivation, and what I could do to help others in similar situations.

My conversations with many others through my years of study taught me that people suffer like demotivating and discouraging similar situations in music careers quite often, and that the relationships between music teachers and students, or parents and musical children, can be quite harmful. I specialized in constructivism-I wanted to find the roots of the problem-but I never gave up on the idea of playing again someday. For me, the world of competitions, awards, and studying in important conservatoires was over. And everybody knows what that means: you can never have a career without any of those things in this neoliberal world.

On the other hand, I enjoyed being a researcher. I found the answers to my questions and enjoyed success in my academic life that was supposed to have come from my music career. That said, as a constructivist, I honestly couldn't care less about success anymore.

Research makes me passionate, and I feel I have complete control. Nobody has bullied me, and if they tried, I remained strong. Enough is enough. I have great confidence, and I never do things anymore because someone else expects me to, or because I am special. I do them because I enjoy them. And I understand now how bullies are weak, so I pity them and don't get angry anymore. Everybody suffers. And our actions come from our motivations.

In the last stages of my Ph.D., I met the man who later would become my husband, a musician who specialized in historically informed performance. That gave me some more answers. The problem is not only the relationships between teachers and students, but also the methods of teaching, which are usually traditional and reproductive, aimed at passing exams and competing with others rather than building individual voices. This is connected to the presence of heavy 
criticism and competition among musicians in music institutions in relation to the importance of talent (Kingsbury 1988).

People who specialize in early music-music from the past played on historical instruments-unfortunately believe that as well. But in its very essence, early music focuses on the inspiration behind the notes, and trying as many possibilities for expression as possible. Models are sources of inspiration, but not examples to be copied, because one has to be genuine in early music, or so it was for many people until recently.

That idea gave me renewed enthusiasm, so I wanted to try again. Well, that and because my partner didn't make me want to feel unattractive, unimaginative, and ignorant, but instead to just be myself. He believed in me and saw that special talent that others had once seen in me.

I eventually found the place that would become my home "affectively, materially, and symbolically." (Chawla and Holman Jones 2015, 180)

\section{Epiphony 5}

The past, home, is not a perfect memory-it will not save us. But we do go home, don't we, to that place where we think we'll find ourselves? (St. Pierre 2008, 122).

So, while finishing my Ph.D., I started a masters' in Period Cello Performance. After a few months of slowly getting back to practice, I started playing 10 minutes at a time. My hands were hurting so much. I would stop for a month because I felt depressed. Then I would add 15 minutes and cry about how unlucky I had been. But eventually, I rehabilitated, and I played well.

I wasn't interested in a degree, being almost 30 years old at the time and almost a PhD teaching at the university level. I was rather more interested in learning and I thought being in touch with other students with rather interesting mindsets would be beneficial.

One of the few pieces that helped me find my voice was a solo ricercar in $G$ minor for cello by Gabrielli. In my teacher's opinion, this music was not so 
interesting from the compositional point of view, but important for understanding where the cello comes from. As I like challenges and disagreed very much with him in this particular case, I said, "I will show you that you are wrong."

And so I did, because he later agreed that the pieces turned out to be incredibly beautiful when approached as I did. He then wanted to re-learn them and play them again.

\section{-AUDIO LINK-}

Caption for Audio Clip 4: Ricercare N.1 in G minor for solo cello by Domenico Gabrielli, played by the author on a baroque cello in $464 \mathrm{~Hz}$ (taken from the author's debut CD and shared with permission from Alba Records; catalogue reference ABCD412).

I just finished recording my first CD, of Gabrielli's (and Scarlatti's) complete cello music. I have my own recording and I did not have to win any competitions to secure a recording contract. And then the reviews came-they were positive, praising.

And you feel this is the time you could stop. You have achieved your goals as a musician by releasing a physical product, and you are at peace with yourself, after all that has happened. Now it is only your decision whether to go on or stop, but you made it. You made a recording, and people know that not everybody can do that. Quantitative measures for a subjective field, what a paradox. According to neoliberal standards, you are worth it.

In any case, as I never thought playing would be possible again, I feel incredibly complete and happy. I now do things because I am passionate about them, and not for career reasons. And I continue as a researcher, also because I enjoy it.

Lately, I have found a way to combine my academic and artistic sides, as I see myself fully capable of doing both. And to my great surprise, I have even gotten grants and many different kinds of support to do this. As for the last three years, I am working with the complete works of Beethoven and Mendelssohn, combining the perspectives of psychology, education, and musicology, through the combination of arts based research, autoethnography, and mixed-methods research. I have played in festivals, even as a soloist, and I have inspired people to cry during concerts once again. I recovered from trauma(s).

I had to be honest and tell it all: I don't "write so the darkness cannot win" (Poulos 2017, 38), but better so that light will surely win. 


\section{Exegesis}

In writing an autoethnography stimulated by procedural, episodic, and implicit memory, my very own "I" would become a collective "I" (McClaurin 2012)-an "I" that is not supposed to be singular, but insistently collective. (Callier, Hill, and Waters 2017)

Musicians use a vocabulary of symbols, sounds, and movement that become useful to metaphorically describe certain feelings and experiences where words and numbers inevitably fail. Sound represents a pathway to resurrect certain embodied events in musicians' lives in words. That is the world of embodied cognition (e.g. Johnson 2007) and representational redescription (Karmiloff-Smith 1992)-a world crucial to any instrumentalist.

Before I get into the contextualization of the written "aesthetic data" above, I follow Adams (2017) in the importance of articulating the autoethnographic perspectives in academic writings such as the one presented here. I called my stories 'Epiphonies'-a term that refers to a "realization that is evoked through sound"-(Gouzouasis 2013, 74), inspired by the feature of sharing epiphanies often found in autoethnographic writings (Ellis, Adams, and Bochner 2011; Gouzouasis and Ryu 2015). A few months ago, I got the strength to "resurrect" the specific pieces that I had not been able to play for several years.

I made a wholehearted effort to invoke true memory through music audiation that played an important role in my life, particularly connected to trauma in some of the epiphanies. I wanted to create a thickness of duration-an épaisseur (Bergson 1969) of the superposition of past and present experiences that would make the stories alive, real, and near to the readers' hearts, by embodying first and foremost a methodology of the heart (stealing the beautiful book title of Pelias 2004).

The story presented herein is not an autobiography, but is more accurately an autoethnography, as it is contextualized and analyzed through motivation and emotion theories partly after each epiphony and more profoundly as this exegesis unfolds. I am a product of a music culture-Western Classical Music-and I acknowledge that many others before and after me have likely experienced similar 
pitfalls and 'silences' and can therefore resonate with my vignettes (see 'resonance' as a rendering for $\mathrm{a} / \mathrm{r} / \mathrm{t} /$ ography; Gouzouasis 2006).

My chosen autoethnographic approaches-evocative (e.g. Bochner and Ellis 2016); interpretive through epiphanies (Denzin 2013) of sound (Gouzouasis 2013); and analytic (e.g. Anderson 2006)-aim at engaging the reader and making clear connections between theory and practice (e.g. Spry 2010; Alexander 2000; Gouzouasis 2017). The epiphonies served as catalysts for reflection on my own life (Etherington 2007). Thus, I purposely used intersubjectivity as a metaphoric, evocative sensitivity when using personal data to analyze and interpret cultural assumptions (in the line of Chang 2008) in the field of music education and classical music performance. As examples, I drew from the importance of the talent account, the exposition to external stressors and competitiveness, and the imbalance of power relations between teachers and parents or students-all of which I discuss below.

The present autoethnography is based on studies that embrace the idea that researchers should be part of the research process as active participants who generate data (e.g., Denzin 2006; Ellis and Bochner 2000), especially when researchers are "members" of the social world they study, and therefore have insider knowledge. I frame these stories within the field of arts-based research (e.g. Leavy 2018; Gouzouasis et al. 2014)-particularly practice as research in the arts (Nelson, 2013)-and aesthetic-based research as pedagogy (Bresler 2018). Following Coessens (2016 para. 34) "a dissolution of the boundaries between the 'creative' and the 'theoretical' has been set in motion here," as I am the researcher with an academic discourse and the musician generating artistic data. And I combine these through aesthetic text to "invoke a polyphony of meanings...metaphorical, pedagogical, and personal, all playing off each other" (Bresler 2018, 649).

Overall, my goal was that of "chang[ing] the world through the way we write about it" (Denzin 2010, 90), particularly the world of classical music instruction, so I could connect "the personal to the cultural" (Ellis and Bochner 2000, 739). I had to be honest and tell it all. I want people to connect with my story, because I have met and continue to meet so many others carrying similar experiences. But I especially want musicians who are suffering to know that if you know the roots of your motivation, you will always be happy and capable of deciding about the direction your life will go. It is never too late, and it is about your own process, not

López-Íñiguez, Guadalupe. 2019. Epiphonies of motivation and emotion throughout the life of a cellist. Action, Criticism, and Theory for Music Education 18 (2): 157-89.

https://doi.org/10.22176/act18.2.157 
anybody else's. Musicians or not, 'this works for everyone.' For this, I believe in the power of autoethnography as pedagogy (e.g. Banks and Banks 2000), particularly in music education settings (i.e. Gouzouasis and Yanko 2018; Gouzouasis and Ihnatovych 2016; Gouzouasis and Leggo 2016; Gouzouasis and Regier 2015; Gouzouasis and Ryu 2015).

In that regard, in this autoethnography I wanted to highlight the urgent need for change in how professional musicians are educated from their earliest years. Research has already verified that Western classical musicians need to spend considerable time rehearsing alone over many years while concentrating on the craft of their instruments. Classical music students often face systemic, authoritarian, and goal- and teacher-centered instruction in the dominating oneto-one methodology present in music education contexts (e.g. Creech 2012; Gaunt 2010; López-Íñiguez, Pozo and de Dios 2014). My story is only one of many examples of this type of instruction.

Such a widespread situation in music studios and the music classroom can potentially create a "culture of concealment" (Carey et al. 2013, 359), a "secret garden" (Young, Burwell, and Pickup 2003, 144), or a "black box" (Rostvall and West 2003, 214). In this context, music pupils could see compromised their autonomy and initiative (Jørgensen 2000), expression (González-Moreno 2014; Burt and Mills 2006), and creativity, and therefore might stop their studies (Hallam 1998). This view has been acknowledged too by the Association of European Conservatoires (AEC), which urges the development of more holistically conceived curricula to vanquish "surprisingly common" approaches that are "almost damaging [to a] student's development as a thoughtful and well-rounded musician" (Cox 2007, 12-13).

I thus want this layered autoethnography to have pedagogical implications for how teachers, parents, and peers take motivation into consideration when dealing with children and teenagers in the music classroom. I want teachers and parents to reflect on the need for an inclusive approach to music education beyond talent (in the line of Green 2008; Jaap and Patrick 2015; Miell, MacDonald, and Hargreaves 2002; Gouzouasis and Ryu 2015). I want them to understand that performance achievement does not have to be a difficult, damaging process in which talent, pressure, and pain are the only determining factors, and to go beyond and reflect upon the importance of cognitive and affective skills and responses 
(Persson 2009). And I want to understand through the lens of my own experiences, the notion of autoethnography as self-pedagogy.

I am publicly opening my heart and my deepest experiences to raise awareness and reflection among teachers and parents, and to offer a bit of hope to students who suffer-an example of survival. Because music is about joy, and not about pain. This is rather important because, as I envision in previous empirical research, music teacher-learner interactions shape the ways that students learn and conceive of music instruction, but also have an impact on their introspection and joyful moments in the music learning experience (López-Íñiguez and Pozo 2014a, 2014b, 2016), and on their learning opportunities (Rostwal and West 2003).

But to engage with pedagogical implications and promote change-or at least reflection-among fellow humans, there are many possibilities. I primarily want to use this essay to purge myself of negative emotions, to develop a sense of agency in my life, something possible through the "learning benefits" of a tragic experience-a catharsis in Aristotelical terms-(Schaper 1968) in the sense that a "project of telling a life is a response to the human problem of authorship, the desire to make sense and preserve coherence over the course of our lives" (Ellis and Bochner 2000, 746).

Thus, this artful autoethnography-this a/r/tographic essay-represented epiphanies through sound that helped me become the person I am (Springgay, Irwin, Leggo, and Gouzouasis 2008). Apart from such a cathartic, musically embodied process, I also had the chance, in line with Levinson (1990), of learning about and expressing my own feelings, confirming my ability to feel deeply, attaining the knowledge that an emotion can be regulated, and connecting to the feelings of the composers of the musical works that I hold so deeply through mostly traumatic or transitionally important life experiences.

One might wonder why I chose the musical pieces presented in this article. I cannot answer. After all, there probably are certain "slippery, intangible aspects of musical experiences, which are highly subjective and charged with emotions and feelings, [that] can often be the focal point of an autoethnographic inquiry" (Gouzouasis and Ryu 2015, 402).

Perhaps I can answer part of that question, as this type of perceptual, aesthetic, and creative event of writing a performative text embellished with my music making enabled me to engage in a reflexive-reflective process, which led to me in developing a deeper understanding of motivation and emotion theories ${ }^{2}$ in

López-Íñiguez, Guadalupe. 2019. Epiphonies of motivation and emotion throughout the life of a cellist. Action, Criticism, and Theory for Music Education 18 (2): 157-89.

https://doi.org/10.22176/act18.2.157 
musicians' lives (in-depth review in Woody and McPherson 2010). Researchers have found that sad music is related to survival and well-being (Habibi and Damasio 2014). In that regard, my emotions toward external stimuli through particularly sad music as described here favored the reestablishment of my "homeostatic equilibrium" (as described by Damasio and Carvalho 2013). I can thus reflexively conclude that the musical pieces actually chose me as real epiphonies because their parameters (e.g. lower overall pitch, slower tempo, use of the minor mode, dull and dark timbres, softer and lower sound levels, legato articulation) included characteristics of sadness (Juslin and Laukka 2004).

But sadness is only one of the emotions found here. Through my rememorizing process, I also found an additional 16 academic emotions throughout my embodied musical experiences, namely joy, enthusiasm, hope, relief, pride, gratitude, admiration, anger, anxiety, hopelessness, shame and guilt, disappointment, boredom, envy, contempt, and surprise (see Pekrun, Goetz, Titz, and Perry 2002). Those emotions represented the mental and physiological feeling states that guided my behavior throughout the past 23 years. In addition, I was able to contextualize my embodied memories through sound into 10 well-researched concepts from the human motivation literature in connection to neuroscienceagency, volition, value, intrinsic and extrinsic motivation, flow, expectancy, selfefficacy, self-regulation, and goals (Ryan 2012)-to analyze how each might be manifested through my stories. These emotions were the reasons behind my voluntary and involuntary behaviors.

For one thing, I noticed a continuous, cyclical shift between extrinsic and intrinsic motivation from the very beginning. I first wanted to study music because others were doing it, but I fell in love by doing it for myself, as I was motivated through curiosity (e.g. Silvia 2012), and I loved to perform for others. When success was calling at my door, my parents and teachers started to press me and give rewards as an exchange for brilliant results. This little effort and the desire for rewards led me to expect rapid results, which made me easily discouraged by failure (Bandura 2008) and (once again) undermined my intrinsic motivation (Deci, Koestner, and Ryan 1999).

At the same time, supportive teachers and positive musical experiences were helping me to reconnect with my internal motivation, but aspects such as social desirability, pride, avoidance of failure, or achievement were bringing up the devil on my left shoulder. I was thus moving between the distinction between

López-Íñiguez, Guadalupe. 2019. Epiphonies of motivation and emotion throughout the life of a cellist. Action, Criticism, and Theory for Music Education 18 (2): 157-89.

https://doi.org/10.22176/act18.2.157 
performance achievement goals and learning goals (e.g. Dweck 1996). In the case of performance goals, when my expectations of success were high, I actively commited to realizing the desired future; when my expectations of success were low, I refrained from doing so. Later, I discovered the importance of self-regulating my learning (e.g. Zimmerman 2000; for a review in music, see López-Íñiguez 2017; Varela, Abramis, and Upitis 2014), to activate and sustain the desired behaviors in connection to the achievement of intrinsically motivating goals. I eventually managed to focus solely on learning. I was simply enjoying the experience, no matter what. I became a constructivist, and a happy learner.

I also framed my epiphonies in terms of their relation to my identity. For instance, I approached the task of playing well in a concert with the goal of identifying myself as a musician, but also in relation to my belief of being able to accomplish musically demanding tasks-self-efficacy-thus feeling agentic (in line with Bandura 1997; 2008). However, self-efficacy was difficult because I had to overcome the environments where I felt excluded (and bullied); the lack of social relatedness obviously compromised my human functioning (Baumeister and Leary 1995; Deci and Ryan 2000). Exclusion, being cursed, hurt me (Macdonald and Leary 2005).

Clearly, building resilience through challenge and motivation for long-term practice should be an important goal in music education in order to build selfefficacy (Bandura 2008) and also performance achievement (Jarvin and Subotnik 2010; Burland and Davidson 2002). In addition, research in the field of educational psychology of music has shown that self-efficacy is highly predictive of performance achievement (McCormick and McPherson 2003; McPherson and McCormick 2006).

It is also important to notice that across cultures (e.g. Chirkov et al. 2003), ages (e.g. Kasser and Ryan 1999) and socioeconomic levels (Williams, McGregor, Sharp, Levesque et al. 2006), people whose basic psychological needs are properly met seem to display greater psychological health, quality motivation, and achievement. Consequently, research points out that people in power procrastinate less while pursuing their goals. They are more resilient, more strategic, and more goal-directed (Guinote 2007).

As I never had much of a power position, according to my cultural and economic background, and my psychological needs were compromised, I physically and mentally experienced Aristotle's concept of akrasia (i.e. the lack of 
willpower). This led to demotivating situations in which I chose antagonistic responses to desired behaviors, such as practicing the cello. And, as it happens with many other women, I internalized a sexually objectifying view on my physicalintellectual self that carried significant consequences for my health and well-being (in-depth review in Roberts and Waters 2012).

Parental support and encouragement during musical studies is crucial (Jarvin and Subotnik 2010; Burland and Davidson 2002), and so is the teacher-pupil relationship (Jarvin and Subotnik 2010). One of the ways in which parents can support performance achievement is by paying for musical instruments and proper instrumental lessons (Davidson, Howe, Moore, and Sloboda 1996; Davidson, Sloboda, and Howe 1996).

In my case, there is evidence that my parents and teachers played a pivotal role in my musical development as they monitored my practice, but also in my psychological development (e.g. Thompson 2006). However, the lack of power (in particular, in terms of my parents in the music industry, partly due to their limited economy and social networks) and their lack of empathy and emotional support in my difficult moments (partly due to lack of understanding and their own life experiences) led to the catastrophic result of me wanting to stop playing and hating my music studies (McPherson 2009). Also, the intense and increasing aspirations of my teachers and parents regarding my musical career led to a total loss of internal control between my intrinsic and extrinsic motivation (in line with Pomenrants, Cheung, and Qin 2012), and a focus on demonstrating versus developing. However-and thankfully-social and early relatedness is not all that matters (Pomerants et al. 2012), and that is why I wrote this article.

Flow occurs during those moments when everything comes together to create a special state of absorption and enjoyment in what one is doing (e.g. Csikzentmihalyi 1990). In the context of music, there must be a musical activity involving physical, social, and cognitive challenges for flow to appear.

For me, flow occurred because I felt highly competent at the beginning of my musical studies thanks to the conductor and some of my teachers' practices, as well as my own interests. The three dimensions of flow I experienced were the loss of self-consciousness, time transformation, and autotelic experience (e.g., Nakamura and Csikszentmihalyi 2002). Flow and intrinsic motivation were thus the keys to getting back to my musician identity later on. Thus, I believe (in line with Custodero 2002) that an approach to instrumental music education should be 
based on flow experience (e.g. Parente 2015) as an enjoyable benefit in the classroom environment. In the end, our experiences in life are what matter most.

One might wonder, after all this, how I got back to playing. Especially when one considers the role my negative emotions might have had on performance anxiety (e.g. Kenny 2010) and given that this is a career fundamentally based on early success and the collection of competitive awards (all lacking in my case), I managed to thrive. One might also wonder how I managed to satisfy my psychological, economical, and contextual needs. And even whether I am able to practice without pain, anxiety, and stress. Or to what extent I experience flow, or stage fright. Or whether I am happy with my body and mind at the moment. I do not always experience consistent flow, and I do have some musculoskeletal pain because of my natural progressive technical development. However, fortunately the rest has improved through a slow-and incredibly painful but pleasurableinternal process.

But there was something else. As we become adults (and in some cases parents), it seems that we shift our goal orientation, looking toward subjective well-being as well as engagement in goal pursuit (in-depth review in Freund, Hennecke, and Mustafić 2012). In my case, getting older and becoming a mother led to a reconnection with my intrinsic motivation and the development of my own unique learner identity.

Freud (1909/1989) argued that an individual has three healthy options after bringing unconscious material into awareness: accept it, reject it, or sublimate it. Such choice is implicated in numerous psychological theories, either as an outcome of some motivational process or as a predictor of motivation. In my case, I undertook them all. But there is more than that, as Bochner $(2012,172)$ brilliantly remarks, the "memory work does not seek to discover precisely what caused me to be the self that I am but rather to confront and deal with the contingencies of my past by redescribing them, so I am not condemned to stay in the bubble of my psychic inheritance."

And so she moves forward, with a little more wisdom, a heart that is more open to love, and with a mind that welcomes deep healing. Pérez "Yung Pueblo" (2017, para. 1) 


\section{Acknowledgements}

This article was made possible thanks to the artistic postdoctoral research project of the author, funded by Kone Foundation, Helsinki (2016-2018) and supported by the Center for Educational Research and Academic Development in the Arts (CERADA) of the University of the Arts Helsinki (Finland).

\section{About the Author}

Guadalupe López-Íñiguez (b. 1983) is a Spanish cellist and interdisciplinary researcher based in Finland. She is Adjunct Professor of Music Education at the Sibelius Academy, University of the Arts Helsinki. She has received awards and funding as a researcher, presents her work regularly at international congresses, and has been published in books and renowned academic journals, in addition to serving as an expert for various journals and institutions. Guadalupe has performed as a soloist on modern, nineteenth-century, and baroque cellos in different festivals and key venues in Europe, Russia, and the US. She has recorded for TV and radio, and her solo recordings have been critically acclaimed. Guadalupe has worked since 2008 as a researcher in various well-funded collaborative research projects related to the psychology of learning and arts education across Europe. Her own artistic and scientific research comprises all her areas of expertise-namely educational psychology of music, historically informed performance, artistic research, and research methodology-in understanding the holistic performance of classical music.

More info: https://guadalupelopeziniguez.com

\section{References}

Adams, Tony E. 2017. Autethnographic responsibilities. International Review of Qualitative Research 10 (1): 62-6.

Alexander, Bruce K. 2000. Skin flint (or, the garbage man's kid): A generative autobiographical performance based on Tami Spry's Tattoo Stories. Text and Performance Quarterly 20 (1): 97-114.

Anderson, Leon. 2006. Analytic autoethnography. Journal of Contemporary Ethnography 35 (4): 373-95.

Bandura, Albert. 1997. Self-efficacy: The exercise of control. New York, NY: Freeman. 
Bandura, Albert. 2008. An agentic perspective on positive psychology. In Praeger perspectives. Positive psychology: Exploring the best in people (Vol. 1), Discovering human strengths, edited by S. J. Lopez, 167-96. Westport, CT: Praeger/Greenwood.

Banks, Stephen P., and Anna Banks. 2000. Reading "the critical life:" Autoethnography as pedagogy. Communication Education 49 (3): 233-8.

Baumeister, Roy F., and Mark R. Leary. 1995. The need to belong: Desire for interpersonal attachments as a fundamental human motivation. Psychological Bulletin 117 (3): 497-529.

Bergson, Henri. 1969. La pensé et le mouvant. Essais et conférences (79th edition). Paris: Les Presses Universitaires de France.

Bochner, Arthur P. 2012. Bird on the wire: Freeing the father within me. Qualitative Inquiry 18 (2): 168-73.

Bochner, Arthur P., and Carolyn Ellis. 2016. Evocative autoethnography: Writing lives and telling stories. New York, NY: Routledge.

Bresler, Liora. 2018. Aesthetic-based research as pedagogy. The interplay of knowing and unknowing toward expanded seeing. In Handbook of arts-based research, edited by P. Leavy, 649-72. New York, NY: Guilford.

Burland, Karen, and Jane W Davidson. 2002. Training the talented. Music Education Research 4 (1): 121-40.

Burt, Rosie, and Janet Mills. 2006. Music students at a UK conservatoire: Identity and learning. Paper presented at the 9th International Conference on Music Perception and Cognition, Bologna, Italy. Retrieved 23 January 2007 from http://www.icmpc2006.org/

Callier, Durell M., Dominique C. Hill, and Hill L. Waters. 2017. Answering the call. Manifesting the spirit of auto/ethnography. International Review of Qualitative Research 10 (1): 13-20.

Carey, Gemma, Ruth Bridgstock, Peter Taylor, Erica McWilliam, and Catherine Grant. 2013. Characterising one-to-one conservatoire teaching: Some implications of a quantitative analysis. Music Education Research 15 (3): 35768.

Chang, Heewon. 2008. Autoethnography as method. Walnut Creek, CA: Left Coast Press. 
Chawla, Devika, and Stacey Holman Jones. 2015. Introduction. In Stories of home: Place, identity, exile, edited by D. Chawla, and S. Holman Jones, xi-xxi. Lanham, MD: Lexington Books.

Chirkov, Valery I., Richard M. Ryan, Youngmee Kim, and Ulas Kaplan. 2003. Differentiating autonomy from individualism and independence: A selfdetermination theory perspective on internalization of cultural orientations and well-being. Journal of Personality and Social Psychology 84 (1): 97-110.

Coessens, Kathleen. 2016. Performative sides/sites of knowledge: Sharing knowledge in artistic ways. Arts and Humanities Higher Education digital issue. AandHHE Reflective Conservatoire Spcecial Issue. Retrieved 23 January 2018 from http://www.artsandhumanities.org/journal/performative-sides sites-of-knowledge-sharing-knowledge-in-artistic-ways/

Cox, Jeremy. 2007. Curriculum design and development in higher music education. Utrecht: European Association of Conservatoires. Retrieved 27 August 2017 from http://bologna-and-music.org/curriculumdesign

Creech, Andrea. 2012. Interpersonal behaviour in one to one instrumental lessons: An observational analysis. British Journal of Music Education 29 (3): 387-407.

Csikzentmihalyi, Mihaly. 1990. Flow: The psychology of optimal experience. New York, NY: Harper and Row.

Custodero, Lori A. 2002. Seeking challenge, finding skill: Flow experience and music education. Arts Education Policy Review 103 (3): 3-9.

Damasio, Antonio. 1999. The feeling of what happens: Body and emotion in the making of consciousness. New York, NY: Harvest Books.

Damasio, Antonio, and Gil B. Carvalho. 2013. The nature of feelings: Evolutionary and neurobiological origins. Nature Reviews Neuroscience 14 (2): 143-52.

Davidson, Jane W., Michael J. A. Howe, Derek G. Moore, and John A. Sloboda. 1996. The role of parental influences in the development of musical performance. British Journal of Developmental Psychology 14 (4): 399-412.

Davidson, Jane W., John A. Sloboda, and Michael J. A. Howe. 1996. The role of parents and teachers in the success and failure of instrumental learners. Bulletin of the Council for Research in Music Education 127: 40-44.

Deci, Edward L., Richard Koestner, and Richard M. Ryan. 1999. A meta-analytic review of experiments examining the effects of extrinsic rewards on intrinsic motivation. Psychological Bulletin 125 (6): 627-68. 
Deci, Edward L., and Richard M. Ryan. 200o. The "what" and "why" of goal pursuits: Human needs and the self-determination of behavior. Psychological Inquiry 11 (4): 227-68.

Denzin. Norman K., ed. 2006. The SAGE handbook of qualitative research. London, UK: Sage Publications.

Denzin, Norman K. 2010. The qualitative manifesto: A call to arms. Walnut Creek, CA: Left Coast Press.

Denzin, Norman K. 2013. Interpretive autoethnography. In Handbook of autoethnography, edited by S. Holman Jones, T. E. Adams, and C. Ellis, 12342. Walnut Creek, CA: Left Coast Press.

Dweck, Carol S. 1996. Implicit theories as organizers of goals and behavior. In The psychology of action: Linking cognition and motivation to behavior, edited by Peter M. Gollwitzer, and John A. Bargh, 69-90. New York, NY: Guilford Press.

Ellis, Carolyn, Tony E. Adams, and Arthur P. Bochner. 2011. Autoethnography: An overview. Forum: Qualitative Social Research 12 (1): 273-90.

Ellis, Carolyn, and Arthur P. Bochner. 200o. Autoethnography, personal narrative, reflexivity: Researcher as subject. In Handbook of qualitative research, edited by Norman K. Denzin, and Yvonna S. Lincoln, 733-68. Thousand Oaks, CA: Sage Publications.

Estés, Clarissa P. 1992. Women who run with the wolves: Myths and stories of the wild woman archetype. New York, NY: Ballentine.

Etherington, Kim. 2007. Ethical research and reflexive relationships. Qualitative Inquiry 13 (5): 599-616.

Freud, Sigmund. 1909/1989. Five lectures on psycho-analysis: The standard edition. New York, NY: Norton and Co.

Freund, Alexandra M., Marie Hennecke, and Maida Mustafić. 2012. On gains and losses, Mmeans and ends: Goal orientation and goal focus across adulthood. In The Oxford handbook of human motivation, edited by Richard M. Ryan, 280300. Oxford, UK: Oxford University Press.

Gaunt, Helena. 2010. One-to-one tuition in a conservatoire: The perceptions of instrumental and vocal students. Psychology of Music 38 (2): 178-208. 
González-Moreno, Patricia A. 2014. Performance creativities in higher music education. In Developing creativities in higher music education: International perspectives and practices, edited by Pamela Burnard, 87-98. New York, NY: Routledge.

Gouzouasis, Peter. 2017. A/r/tographic inquiry in a new tonality: The relationality of music and poetry. In Handbook of arts based research, edited by Patricia Leavy, 233-46. New York, NY: Guilford Press.

Gouzouasis, Peter. 2013. The metaphor of tonality in artography. The UNESCO Observatory E-Journal, 3(2). Retrieved 24 August 2017 from http://web.education.unimelb.edu.au/UNESCO/ejour-nal/index.html

Gouzouasis, Peter. 2006. Music in an a/r/tographic tonality. Journal of the Canadian Association for Curriculum Studies 5 (2): 33-59.

Gouzouasis, Peter, and Matthew Yanko. 2018. Reggio's arpeggio: Becoming pedagogical through autoethnography. In Meaning making in early childhood research: Pedagogies and the personal, edited by Jeanne Marie Iorio and Will Parnell, 56-70. New York, NY: Routledge.

Gouzouasis, Peter, and Diana Ihnatovych. 2016. The dissonant duet: An autoethnography of a music teacher-student relationship. Journal of the Canadian Association for Curriculum Studies 14 (2): 14-32.

Gouzouasis, Peter, and Carl Leggo. 2016. Performative research in music and poetry: A pedagogy of listening. In The Routledge international handbook of intercultural arts research, edited by Pamela Burnard, Elizabeth Mackinlay, and Kimberly Powell, 454-66. Oxfordshire, UK: Taylor and Francis/Routledge.

Gouzouasis, Peter, and Chris Regier. 2015. Adolescent love and relationships: An autoethnography of songwriting and guitar playing. Journal of Artistic and Creative Education 9 (1): 68-98.

Gouzouasis, Peter, and Jee Yeon Ryu. 2015. A pedagogical tale from the piano studio: autoethnography in early childhood. Music Education Research 17 (4): 397-420.

Gouzouasis, Peter, Danny Bakan, Jee Yeon Ryu, Helen Ballam, David Murphy, Diana Ihnatovych, Zoltan Virag, and Matthew Yanko. 2014. Where do teachers and learners stand in music education research? A multi-voiced call for a new ethos of music education research. International Journal of Education \& the Arts 15 (15). Retrieved fromhttp://www.ijea.org/v15n15/ 
Green, Lucy. 2008. Music, informal learning and the school: A new classroom pedagogy. Aldershot, UK: Ashgate.

Guinote, Ana. 2007. Power and goal pursuit. Personality and Social Psychology Bulletin 33 (8): 1076-87.

Habibi, Assal, and Antonio Damasio. 2014. Music, feelings and the human brain. Psychomusicology: Music, Mind and Brain 24 (1): 92-102.

Hallam, Susan. 1998. The predictors of achievement and dropout in instrumental tuition. Psychology of Music 26 (2): 116-32.

Harter, Susan, and Bradley K. Jackson. 1993. Young adolescents' perceptions of the link between low self-worth and depressed affect. The Journal of Early Adolescence 13 (4): 383-407.

Hervas, Gonzalo, and Carmelo Vázquez. 2011. What else do you feel when you feel sad? Emotional overproduction, neuroticism and rumination. Emotion 11 (4): 881-95.

Jaap, Angela, and Fiona Patrick. 2015. Teachers' concepts of musical talent and nurturing musical ability: Music learning as exclusive or as opportunity for all? Music Education Research 17 (3): 262-77.

Jarvin, Linda, and Rena F. Subotnik. 2010. Wisdom from conservatory faculty: Insights on success in classical music performance. Roeper Review 32 (2): 7887.

Johnson, Mark. 2007. The meaning of the body. Aesthetics of human understanding. Chicago, IL: The University of Chicago Press Books.

Jørgensen, Harald. 200o. Student learning in higher instrumental education: Who is responsible? British Journal of Music Education 17 (1): 67-77.

Juslin, Patrick N., and Petri Laukka. 2004. Expression, perception and induction of musical emotions: A review and a questionnaire study of everyday listening. Journal of New Music Research 33 (3): 217-38.

Karmiloff-Smith, Annette. 1992. Beyond modularity: A developmental perspective on cognitive science. Cambridge, MA: MIT Press.

Kasser, Virginia G., and Richard M. Ryan. 1999. The relation of psychological needs for autonomy and relatedness to vitality, well-being, and mortality in a nursing home. Journal of Applied Social Psychology 29 (5): 935-54. 
Kenny, Diana. 2010. The role of negative emotions in performance anxiety. In Handbook of music and emotion: Theory, research, applications, edited by P. N. Juslin, 425-51. Oxford, UK: Oxford University Press.

Kingsbury, Henry. 1988. Music talent and performance: Conservatory cultural system. Philadelphia, PA: Temple University Press.

Leavy, Patricia, ed. 2017. Handbook of arts-based research. New York, NY: Guilford.

Levinson, Jerrold. 1990. Music, art and metaphysics: Essays in philosophical aesthetics. New York, NY: Oxford University Press.

López-Íñiguez, Guadalupe. 2017. Constructivist self-regulated music learning. Finnish Journal of Music Education 20 (1): 134-8.

López-Íñiguez, Guadalupe, and Juan Ignacio Pozo. 2016. Analysis of constructive practice in instrumental music education: Case study with an expert cello teacher. Teaching and Teacher Education 60: 97-107.

López-Íñiguez, Guadalupe, and Juan Ignacio Pozo. 2014a. Like teacher, like student? Conceptions of children from traditional and constructive teachers regarding the teaching and learning of string instruments. Cognition and Instruction 32 (3): 219-52.

López-Íñiguez, Guadalupe, and Juan Ignacio Pozo. 2014b. The influence of teachers' conceptions on their students' learning: Children's understanding of sheet music. British Journal of Educational Psychology 84 (2): 311-328.

López-Î́ñiguez, Guadalupe, Juan Ignacio Pozo, and María José de Dios. 2014. The older, the wiser? Profiles of string instrument teachers with different experience according to their conceptions of teaching, learning, and evaluation. Psychology of Music 42 (2), 157-76. doi:10.1177/0305735612463772

Macdonald, Geoff, and Mark R. Leary. 2005. Why does social exclusion hurt? The relationship between social and physical pain. Psychological Bulletin 131 (2): 202-3.

McClaurin, Irma. 2012. Black feminist auto/ethnography that makes you want to cry. Insight News. Retrieved January 242018 from https://issuu.com/ insightnews/docs/o62512insightnews

McCormick, John, and Gary E. McPherson. 2003. The role of self-efficacy in a musical performance examination: An exploratory structural equation analysis. Psychology of Music 31 (1): 37-51. 
McPherson, Gary E. 2009. The role of parents in children's musical development. Psychology of Music 37 (1): 91-110.

McPherson, Gary E., and John McCormick. 2006. Self-efficacy and music performance. Psychology of Music 34 (3): 322-66.

Mee, Steven, Blynn G. Bunney, Christopher Reist, Steven G. Potkin, and William E. Bunney. 2006. Psychological pain: A review of evidence. Journal of Psychiatric Research 40 (8): 680-90.

Miell, Dorothy, Raymond A. R. MacDonald, and David J. Hargreaves eds. 2002. Musical Communication. New York: Oxford University Press.

Nakamura, Jeanne, and Mihaly Csikszentmihalyi. 2002. The concept of flow. In Handbook of positive psychology, edited by C. R. Snyder, and Shane J. Lopez, 89-105. Oxford, UK: Oxford University Press.

Nelson, Robin. 2013. Practice as research in the arts. Hampshire, UK: Palgrave Macmillan.

Parente, Thomas J. 2015. The positive pianist. How flow can bring passion to practice and performance. Oxford, UK: Oxford University Press.

Pekrun, Reinhard, Thomas Goetz, Wolfram Titz, and Raymond P. Perry. 2002. Academic emotions in students' self-regulated learning and achievement: A program of qualitative and quantitative research. Educational Psychologist 37 (2): 91-105.

Pelias, Ronald J. 2004. A methodology of the heart: Evoking academic and daily life. Walnut Creek, CA: AltaMira Press.

Pérez "Yung Pueblo", Diego. 6.9.2017. Instagram quotation Retrieved 11 January 2018 from https://www.instagram.com/p/BYtAHMGFZOT/?taken-by=yung_ pueblo

Persson, Roland S. 2009. The elusive muse: understanding musical giftedness. In International handbook of giftedness, edited by L.V. Shavinina, 727-50. Dordrecht, NL: Springer Science.

Pomerants, Eva Marie, Cecilia Sin Sze Cheung, and Lili Qin. 2012. Relatedness between children and parents: Implications for motivation. In The Oxford handbook of human motivation, edited by Richard M. Ryan, 335-49. Oxford, UK: Oxford University Press.

López-Íñiguez, Guadalupe. 2019. Epiphonies of motivation and emotion throughout the life of a cellist. Action, Criticism, and Theory for Music Education 18 (2): 157-89.

https://doi.org/10.22176/act18.2.157 
Poulos, Christopher N. 2017. Autoethnography. A manifestory. International Review of Qualitative Research 10 (1): 33-8.

Pozo, Juan Ignacio. 2008. Aprendices y maestros: La Psicología cognitiva del aprendizaje [Apprentices and teachers: The cognitive psychology of learning] (2nd ed.). Madrid: Alianza.

Roberts, Tomi-Ann, and Patricia L. Waters. 2012. The gendered body project: Motivational components of objectification theory. In The Oxford handbook of human motivation, edited by Richard M. Ryan, 323-34. Oxford, UK: Oxford University Press.

Rostvall, Anna-Lena, and Tore West. 2003. Analysis of interaction and learning in instrumental teaching. Music Education Research 5 (3): 213-26.

Ryan, Richard M., ed. 2012. The Oxford handbook of human motivation. Oxford, UK: Oxford University Press.

Schaper, Eva. 1968. Aristotle's catharsis and aesthetic pleasure. The Philosophical Quarterly 18 (71): 131-43.

Silvia, Paul J. 2012. Curiosity and motivation. In The Oxford handbook of human motivation, edited by Richard M. Ryan, 157-66. Oxford, UK: Oxford University Press.

Sloboda, John A. 1996. The acquisition of musical performance expertise: Deconstructing the 'talent' account of individual differences in musical expressivity. In The road to excellence: The acquisition of expert performance in the arts and sciences, sports and games, edited by K. Anders Ericsson, 107126. Mahwah, NJ: Erlbaum.

Springgay, Stephanie, Rita L. Irwin, Carl Leggo, and Peter Gouzouasis, eds. 2008. Being with $a / r / t /$ ography. Rotterdam: Sense Publishers BV.

Spry, Tammy. 2010. Call it swing: A jazz blues autoethnopgraphy. Cultural Studies -Critical Methodologies 10 (4): 271-82.

St. Pierre, Elisabeth A. 2008. Home as a site of theory: A fragment. International Review of Qualitative Research 1 (2): 119-24.

Thompson, Ross A. 2006. The development of the person: Social understanding, relationships, conscience, self. In Handbook of child psychology (Vol. 3), Social, emotional, and personality development (6th edition), edited by N. Eisenberg, 24-98. Hoboken, NJ: Wiley. 
Varela, Wynnpaul, Philip C. Abrami, and Rena Upitis. 2014. Self-regulation and music learning: A systematic review. Psychology of Music 44 (1): 55-74.

Von Glasersfeld, Ernst. 1995. A constructivist approach to teaching. In Constructivism in education, edited by L.P. Steffe and J. Gale, 3-16. Hillsdale, NJ: Erlbaum.

Williams, Geoffrey C., Holly A. McGregor, Daryl Sharp, Chantal Levesque, Ruth W. Kouides, Richard M. Ryan, and Edward L. Deci. 2006. Testing a selfdetermination theory intervention for motivating tobacco cessation: Supporting autonomy and competence in a clinical trial. Health Psychology 25 (1): 91-101.

Woody, Robert H., and Gary E. McPherson. 2010. Emotion and motivation in the lives of performers. In Handbook of music and emotion: Theory, research, applications, edited by Patrick N. Juslin, 401-424. Oxford, UK: Oxford University Press.

Young, Vanessa, Kim Burwell, and David Pickup. 2003. Areas of study and teaching strategies in instrumental teaching: A case study research project. Music Education Research 5 (2): 139-55.

Zimmerman, Barry J. 2000. Attaining self-regulation: A social cognitive perspective. In Handbook of self-regulation, edited by M. Boekaerts, P. R. Pintrich, and M. Zeidner, 13-39. San Diego, CA: Academic Press.

\section{Notes}

${ }^{1}$ To become so, 1) I ate tons of white bread with incredible speed and sat for hours on the toilet thinking whether I should vomit or not (I never did); 2) I harmed myself by strongly pressing my face causing a skin infection; and 3) I stopped practicing and I took on the role of a trophy girlfriend. This continued until the 'Epiphony 5 ' of the present essay.

2 Please note that the common Latin root word of emotion and motivation is movere (to move). 